\title{
Biofilm Research in Bovine Mastitis
}

\author{
Regitze Renee Pedersen ${ }^{1}$, Volker Krömker ${ }^{2}$, Thomas Bjarnsholt ${ }^{3,4}$, \\ Kirstin Dahl-Pedersen ${ }^{1}$, Rikke Buhl ${ }^{1}$ and Elin Jørgensen ${ }^{3 *}$
}

${ }^{1}$ Department of Veterinary Clinical Sciences, University of Copenhagen, Copenhagen, Denmark, ${ }^{2}$ Department of Veterinary and Animal Sciences, University of Copenhagen, Copenhagen, Denmark, ${ }^{3}$ Department Immunology and Microbiology, Costerton Biofilm Center, University of Copenhagen, Copenhagen, Denmark, ${ }^{4}$ Department of Clinical Microbiology,

Copenhagen University Hospital, Copenhagen, Denmark

OPEN ACCESS

Edited by:

Alejandra Andrea Latorre,

University of Concepción, Chile

Reviewed by:

Bharat Bhanderi,

Anand Agricultural University, India

Mohanned Naif Alhussien,

Technical University of

Munich, Germany

*Correspondence:

Elin Jørgensen

elin.jorgensen@sund.ku.dk

Specialty section:

This article was submitted to Veterinary Infectious Diseases,

a section of the journal

Frontiers in Veterinary Science

Received: 21 January 2021 Accepted: 09 April 2021

Published: 07 May 2021

Citation:

Pedersen RR, Krömker V, Bjarnsholt T,

Dahl-Pedersen K, Buhl R and

Jørgensen E (2021) Biofilm Research

in Bovine Mastitis.

Front. Vet. Sci. 8:656810.

doi: 10.3389/fvets.2021.656810
Bovine mastitis is one of the most important diseases in the dairy industry and has detrimental impact on the economy and welfare of the animals. Further, treatment failure results in increased antibiotic use in the dairy industry, as some of these mastitis cases for unknown reasons are not resolved despite standard antibiotic treatment. Chronic biofilm infections are notoriously known to be difficult to eradicate with antibiotics and biofilm formation could be a possible explanation for mastitis cases that are not resolved by standard treatment. This paper reviews the current literature on biofilm in bovine mastitis research to evaluate the status and methods used in the literature. Focus of the current research has been on isolates from milk samples and investigation of their biofilm forming properties in vitro. However, in vitro observations of biofilm formation are not easily comparable with the in vivo situation inside the udder. Only two papers investigate the location and distribution of bacterial biofilms inside udders of dairy cows with mastitis. Based on the current knowledge, the role of biofilm in bovine mastitis is still unclear and more in vivo investigations are needed to uncover the actual role of biofilm formation in the pathogenesis of bovine mastitis.

\section{Keywords: biofilm, bovine mastitis, chronic infections, antimicrobial resistance, antimicrobial therapy}

\section{INTRODUCTION}

Bovine mastitis is an important disease in the dairy industry with severe consequences for the welfare of dairy cows and the economy of the industry (1). Antibiotic treatment of bovine mastitis account for the highest antibiotic use in the dairy industry (2).

Bovine mastitis is defined as inflammation of the mammary gland and is most commonly caused by bacterial infection (3). Bovine mastitis occurs in two different clinical manifestations; subclinical and clinical mastitis, and ranges from mild, moderate to severe cases. Subclinical mastitis can be diagnosed by tests, e.g., the somatic cell count in milk, however, no clinical signs are apparent (4). Clinical mastitis manifests with visible changes to the milk in the form of clots or flakes and clinical signs of infection and inflammation, such as fever, redness, pain, and swelling of udder and lymph nodes (4). Some cases of bovine mastitis resolve themselves and most cases resolve after standard antibiotic treatment (2), however, some cases can progress to a detrimental point where the cow is culled, and in severe cases, spontaneous death may even occur $(1,4)$.

The most common infectious agents of bovine mastitis are Staphylococcus aureus, Streptococcus agalactiae (2), Escherichia coli (5), and Streptococcus uberis (6). S. aureus is a common and challenging mastitis pathogen, as $S$. aureus has a high persistence rate $(7,8)$ and a low bacteriological cure rate in clinical mastitis cases (9). During bovine mastitis, bacteria potentially upregulate expression of virulence factors that can lead to higher resistance to phagocytosis (10) 
and upregulation of genes that destruct host tissue and the ability of the host cells to capture iron, e.g., lactoferrin (11). The pathogens are adapted to infection of the tissue in the mammary gland by a broad variety of virulence factors, e.g., the propensity to invade and escape host cell defenses by hemolysins (12), adhesion to host cells and production of leukotoxins to destroy monocytes and polymorphonuclear cells (12). Further, some of the pathogens are low shedders (13) and some form biofilm (12). All resulting in pathogens capable of causing longlasting infections.

Bovine mastitis is normally treated with antibiotics, however, in some cases, the antibiotics are not resolving the disease and the infection becomes chronic. Continued antibiotic treatment in these cases where antibiotics do not eradicate the microbial agents increases the risk of developing antibiotic resistance, which is one of the greatest threats to human and animal health (14).

Chronic and recurrent cases of bovine mastitis share similar characteristics with chronic biofilm infections observed in humans and other animals. Biofilm is defined as "a coherent cluster of bacterial cells imbedded in a biopolymer matrix, which, compared with planktonic cells, shows increased tolerance to antimicrobials and resists the antimicrobial properties of the host defense" (15), however the role of matrix is unclear in vivo (16). Biofilm is suggested to be the default mode of growth for bacteria (17). Antibiotic treatment of biofilm infections is often unsuccessful and thus the infections are difficult to eradicate (18, 19). Being part of a biofilm can provide protection for the bacteria against threats from the environment, including antibiotics and host defenses (20).

The role of biofilm in human infections has been an expanding research field since bacterial aggregates were observed in 1977 in the lungs of patients with cystic fibrosis (21), and since 1982 where the first report on a medical biofilm causing recurrent infection (bacteremia) was described (22). However, in veterinary medicine, few reports exist on biofilms' direct role in infections, as most literature focuses on in vitro characteristics of pathogenic bacteria/biofilms and not their role in vivo.

In human medicine, biofilms are known to contribute to a wide variety of infections and diseases including wound infections, implant related infections, lung infections, osteomyelitis, chronic otitis media, urinary tract infections, chronic sinusitis, dental plaque, endocarditis, etc. (23). Pseudomonas aeruginosa biofilm infection in cystic fibrosis patients is one of the most well-studied biofilm infections to date, and intense research has revealed both pathogenetic, diagnostic, and therapeutic breakthroughs, and has increased the life expectancy of these patients dramatically (24-26). Biofilms are found in the majority of human chronic wounds and are considered to play a consistent role in the pathogenesis of impaired wound healing (27-29). Major biofilm pathogens in chronic wounds are $S$. aureus, $P$. aeruginosa, and Enterobacteriaceae $(27,30,31)$. Implant related infections are often also driven by biofilms that cause low grade, difficult to detect infections with delayed onset $(32,33)$. Biofilm infections are thus important and are estimated to account for 550,000 deaths and 17 million infections yearly in the USA (34).
Understanding the role of biofilm in bovine mastitis will potentially unlock new treatment options and avoid unnecessary antibiotic treatment. If thereby being able to cure these chronic and recurrent bovine mastitis cases, the economy of the dairy industry, as well as animal welfare will improve and use of antibiotics will decrease.

In this paper, we review the literature on the development of bovine mastitis biofilm research with focus on the last two decades. In addition, we review the methods applied in published research and propose new methods for future research of biofilms' role in bovine mastitis.

\section{DEVELOPMENT OF RESEARCH OF BOVINE MASTITIS}

The first studies investigating biofilm forming abilities of bovine mastitis pathogens emerged in the early 1990s. In 1993, "slime production" (exopolysaccharide matrix) was observed in bovine coagulase-negative staphylococci (CNS) strains. This slime production was observed in vitro by using the tube method together with Congo Red Agar plates and suggested that the slime-production functioned as a virulence factor (35). Later, strains of $S$. aureus isolated from bovine mastitis cases were found to bind to milk fat globules. This suggested that the bacteria were in a biofilm mode of growth in vitro (36). During the first decade of 2000, most papers concentrated on investigating the in vitro biofilm forming abilities of S. aureus and Staphylococcus epidermidis isolates from bovine mastitis cases (37-39), the genes that were associated with biofilm formation (39-41), the susceptibility to antimicrobial agents (42), and potential treatment options against biofilm infections (43-45).

After 2010, the research of biofilm in bovine mastitis accelerated, and during the last decade, over 170 studies have been published. The focus of the research is still the in vitro biofilm forming abilities of bovine mastitis pathogens but also investigations of antibiotic resistance, molecular investigations of biofilm related genes, and the search for potential treatments and vaccines; the majority of these paper have focused on S. aureus. In only two in vivo studies, bacterial biofilms have been directly identified in bovine udders with mastitis $(46,47)$.

\section{BIOFILM METHODS APPLIED TO THE RESEARCH OF BIOFILM IN BOVINE MASTITIS}

\section{Methods Used for Investigation of Biofilm Forming Abilities of Bovine Mastitis Pathogens}

The biofilm forming abilities of bovine mastitis pathogens in vitro have been investigated by multiple traditional biofilm methods. Most studies have focused on bacterial isolates from milk samples of bovine mastitis cases and the main focus has been on $S$. aureus, a well-known in vitro biofilm producer (48) and one of the most common pathogens in chronic bovine mastitis (49). The majority of the studies, i.e., more than 140 papers, have been using microtiter plates with crystal violet staining for 
quantification of the bacterial biomass. When using this biofilm assay, the bacteria are grown in polystyrene microtiter plates. The wells are emptied and washed at different time points, whereby the remaining biofilm biomass can be stained and quantified with crystal violet $(50,51)$. The crystal violet stain is used to quantify the total biomass in these system, as the stain binds to negatively charged molecules, which means to both the bacteria and exopolysaccharides (50). S. aureus is the most common species investigated using the microtiter assay in biofilm and bovine mastitis research to investigate its ability to form biofilm in vitro. Multiple studies found that majorities of $S$. aureus isolates from bovine mastitis cases can form biofilm in vitro by this assay (52-54). Applying the same method, $20-30 \%$ of $S$. agalactiae mastitis isolates also showed biofilm forming abilities in vitro when cultivated in different atmospheric conditions and growth media (55-57). This assay was also used to investigate the biofilm forming abilities of 53 mastitis isolates of Klebsiella spp. and 17 Pseudomonas aeruginosa mastitis isolates, all isolates were able to form biofilm $(58,59)$.

Although not as common as the crystal violet assay, several studies use the Congo Red Agar (CRA) test. The CRA method was developed by Freeman et al. (60) in 1989 for "detecting the production of slime by coagulase-negative staphylococci." The "slime-forming" strains are black and the strains not capable of forming slime appear red on the agar (60). The CRA test is a qualitative method to estimate whether staphylococci isolates are able to produce biofilm in vitro and is often followed by a quantitative assay-such as the tube method or the microtiter assay. Half of $S$. aureus isolates from dairy cows with subclinical mastitis were able to produce biofilm by the CRA method $(61,62)$.

In the standard tube method, bacteria are cultivated in culture tubes, washed and then stained with crystal violet, safranine, or other stains. Biofilm production is observed by color on the sides and bottom of the tube (63). When the biofilm forming ability of $S$. aureus isolates from bovine mastitis cases was investigated by the tube method using safranine stain, $25-70 \%$ of the isolates were able to form biofilm $(61,64,65)$.

Using yet another staining method, $\sim 85 \%$ of CNS isolates from mastitis milk samples were able to form biofilm when their biofilm forming ability was investigated by the microtiter assay and stained using the LIVE/DEAD technique with subsequent confocal laser scanning microscopy (CLSM) to study the composition of the matrix (66). Confocal laser scanning microscopy is widely used in the visualization of medical biofilm, as some of the advantages of this technique are the possibility to visualize 3D and spatial structures of biofilms (51). Furthermore, it is possible to quantify volume and other parameters of the biofilm and to apply different fluorescent probes (51).

Quantitative and qualitative assays for investigating the biofilm forming abilities of bovine mastitis pathogens in vitro are inexpensive, fairly simple and fast. In the last years, microscope techniques have become more accessible and would facilitate more detailed investigations of the biofilm phenotype and interactions between antimicrobial compounds and biofilms.

\section{Investigations of Antimicrobial Compounds Against Biofilm Forming Mastitis Pathogens}

Different antimicrobial compounds and antibiotics have been tested on bovine mastitis isolates' ability to form biofilm. The biofilm forming ability of $E$. coli in the presence of different antibiotics was investigated using CLSM and revealed increased adhesion of the isolates (67) and a greater biofilm formation of E. coli bovine mastitis isolates in the presence of enrofloxacin (68). When grown as biofilms, S. aureus bovine mastitis isolates are highly resistant to antimicrobial agents (42). The antibacterial use of the traditional medicinal plant Plectranthus ornatus (spur flowers) used in Brazil for treatment of skin infections was investigated for its anti-biofilm properties by using the plant as a herbal soap on gloves contaminated with $S$. aureus from dairy cows with bovine mastitis. There was no microbial growth after the gloves were submerged in the herbal soap and when the biofilm inhibitory concentration by microtiter plates and crystal violet staining was investigated, the plant was able to inhibit biofilm formation (69). Anti-biofilm agents against $S$. aureus have also been investigated in vivo. Ethanolic extracts from the leaves of Rhodomyrtus tomentosa (rose myrtle) were investigated as a possible antimicrobial agent against biofilm producing $S$. aureus in combination with the antibiotic pirlimycin. When extracts were used alone, there was no significant reduction in the bacterial load in a murine mastitis model. In combination with the antibiotic, a significant antibacterial effect was observed, but there was no significant difference between the antibiotic used alone compared with the combination of antibiotics and extract (70). The possible inhibitory effect of the Argentinian medicinal plant Minthostachys verticillata was tested on Escherichia coli, Bacillus pumilus, and Enterococcus faecium isolated from mastitis milk. The essential oil of the plant had inhibitory effect on the production of biofilm of all isolates in 96 well-microtiter plates (71). The naturally occurring signaling molecule of bacteria, cyclic dinucleotide $3^{\prime}, 5^{\prime}$-cyclic diguanylic acid (c-di-GMP), has been investigated to inhibit biofilm formation of $S$. aureus, and a decrease in the colonization of the pathogen in the mammary glands was shown in a murine mastitis model (44). The alternative drug, 1-hydroxyanthraquinone, was found to have a significant inhibitory action against Staphylococcus xylosus in vitro as well as a reduction in inflammation in the mammary glands of murine models (72).

\section{Biofilm-Associated Genes in Bovine Mastitis Pathogens}

The molecular identification of pathogens is another direction in the research of biofilm in bovine mastitis and several studies have investigated different biofilm-associated genes of bovine mastitis isolates. The intercellular gene cluster adhesion operon (ica) is one of the genes that has been investigated for its role in biofilm formation and has been found in $40 \%$ of S. aureus isolates from bovine mastitis by analyzing their biofilm forming abilities within the microtiter assay and then sequencing the isolates (73). However, whether the isolates carrying the ica genes actually produce biofilm in vitro, depends on the biofilm assay. Some 
studies found that even if the isolates carried the ica genes, not all of the isolates produced biofilm in the microtiter plate (74) and that some isolates would form black colonies (indicating slimeformation) when grown on CRA plates but not necessarily form biofilm in the microtiter assay (41). Biofilm-associated proteins (bap) has been researched by several bovine mastitis studies and $S$. aureus isolates have been investigated for the presence of bap genes and their biofilm forming ability (40). A study found that over $90 \%$ of isolates carried icaADBC genes and of these $25 \%$ carried the bap genes. When the isolates were positive for both icaADBC and bap, they were strong biofilm producers in vitro, however, when only positive for icaADBC, they produced less biofilm. The role of bap was investigated by constructing a mutant only positive for bap and found that the mutant had the same biofilm forming capacity as the wild type (40). However, in other studies, the bap gene was not found at all in $S$. aureus isolates from bovine mastitis cases $(39,74)$.

\section{OTHER TOPICS ADDRESSED IN THE RESEARCH OF BIOFILM IN BOVINE MASTITIS}

\section{Multispecies Biofilm}

The research of bovine mastitis and biofilm often focuses on one specific pathogen and its ability to form biofilm in vitro. When only single species are investigated, there is a risk of overseeing keystone species (75) or possible interactions between commensals and pathogens or amongst pathogens, which might be important in the understanding of biofilms' role in bovine mastitis. However, the majority of studies investigating the role of biofilm in bovine mastitis focuses solely on $S$. aureus. In the environment, there is often more than one bacterial strain present and multispecies biofilms are commonly observed (76). Bovine mastitis infections can have multiple bacterial agents (9) and it is also important to consider the possible role of commensal bacteria in udders. Lactic acid bacteria (LAB) are commonly isolated from the teat canals and milk of dairy cows (77). Wallis et al. investigated the effect of growing two probiotic LAB strains together with a challenge between biofilm of probiotic LAB and $S$. aureus biofilm. They observed that when two LAB strains were co-cultured with $S$. aureus, it resulted in no growth of $S$. aureus, suggesting the beneficial use of probiotic bacteria against pathogenic biofilms in bovine mastitis (78). The presence of specific bacteria can either promote or decrease growth of other bacteria $(79,80)$ and the competition between these bacteria can cause damage to the surrounding environment or tissue (81). Immune responses toward bacteria and biofilm may similarly cause collateral damage to the surrounding tissue (82). Therefore, it is important to consider possible interactions between other bacteria and bovine mastitis pathogens as well as between pathogens and the immune response.

\section{Potential Vaccines Against Biofilm Forming Mastitis Pathogens}

Two mastitis vaccine candidates against $S$. uberis have shown a significant reduction in the mortality of mice infected with the pathogen (83). Different candidates for a $S$. aureus vaccine is currently being investigated; in one study, live-attenuated small-colony variants have shown promising results compared to inactivated bacteria in murine models (84). However, in another study, a formalin-killed whole-cell vaccine candidate of $S$. aureus biofilm showed a significant reduction in the colonization of $S$. aureus in the udder in vaccinated mice compared to mice vaccinated with a vaccine candidate from planktonic $S$. aureus (85). A killed bacterin vaccine candidate against $S$. aureus was tested in primiparous gestating cows. There were no observations of any prevention of intramammary infection by $S$. aureus but a reduced multiplication of $S$. aureus in the mammary glands was observed (86). S. aureus' protein A has also been investigated as a possible vaccine target and a vaccine candidate has shown a significant reduction in bacterial load of the mammary glands of pregnant mice. However, the immunized mice were not protected when they subsequently were infected with biofilm producing encapsulated $S$. aureus (87). Currently, two mastitis vaccines are available on the market against $S$. aureus and $S$. uberis from the company HIPRA (Amer, Spain).

\section{In vivo Investigations of Biofilm in Bovine Mastitis}

Most of the so-called in vivo investigations of biofilm in bovine mastitis have used experimental models (mice and sheep), and the majority of these studies focused on anti-biofilm treatment or vaccines against biofilm udder infections (Table 1) $(44,69,70,72$, 83-85). Only a few studies investigated and confirmed biofilm in vivo within udder tissue of dairy cows with bovine mastitis. Two studies directly detected biofilm inside udders of dairy cows with mastitis. Clustering of $S$. aureus bacteria in udders of dairy cows with bovine mastitis were observed by microscopy to be located in the lumen of the alveoli and lactiferous ducts of the udders of experimentally infected dairy cows (47). In another study, the presence of biofilm was investigated directly in the udders of dairy cows by collecting swabs from the udders of slaughtered dairy cows with $S$. aureus infection. Swabs were obtained from the teat cistern, gland cistern, and parenchyma and were subsequently stained using immunofluorescence staining of polysaccharide intercellular adhesions (PIA), which is a component of the $S$. aureus biofilm matrix. The samples were investigated by fluorescence microscopy and PIA was found in 71 out of 184 swabs (46).

\section{The Bovine Mammary Immune Response to Biofilm Infection}

The response to infections is crucial for the survival of mammals. The response mechanisms to bacterial and viral infections are widely investigated, however much less is known about the immune response toward biofilm. As per definition, host immune responses are tolerated by biofilms, and no specific anti-biofilm immune responses have been identified (82).

The protection against infectious agents in the bovine mammary gland has been recently reviewed by Sordillo (93). As for biofilm infections in general, the mammary gland response toward bacterial biofilms is not fully understood yet, and as 
TABLE 1 | Studies investigating biofilm forming bovine mastitis pathogens in animal models or the effect of possible antibacterial agents and vaccines in animal models.

\begin{tabular}{|c|c|c|c|c|c|}
\hline References & Year & Sample type & Focus of study & Pathogen & Experimental animal \\
\hline Cucarella et al. (88) & 2001 & $\begin{array}{l}\text { Bovine subclinical mastitis } \\
\text { and human isolates }\end{array}$ & Molecular basis of biofilm & S. aureus & Mice \\
\hline Brouillette et al. (44) & 2005 & $\begin{array}{l}\text { Clinical bovine mastitis } \\
\text { isolates }\end{array}$ & Antibacterial treatment & S. aureus & Mice \\
\hline Gogoi-Tiwari et al. (85) & 2015 & Bovine mastitis isolates & Vaccine & S. aureus & Mice \\
\hline Collado et al. (83) & 2016 & $\begin{array}{l}\text { Clinical bovine mastitis } \\
\text { isolates }\end{array}$ & Vaccine & S. uberis & Mice \\
\hline Gogoi-Tiwari et al. (87) & 2016 & Bovine mastitis isolates & Vaccine & S. aureus & Mice \\
\hline Mordmuang et al. (70) & 2019 & Bovine mastitis isolates & Antibacterial treatment & S. aureus & Mice \\
\hline Montironi et al. (89) & 2019 & $\begin{array}{l}\text { Subclinical bovine mastitis } \\
\text { isolates, milk samples }\end{array}$ & $\begin{array}{l}\text { Investigation of phenotype, } \\
\text { genotype and virulence }\end{array}$ & Enterococcus faecium & Mice \\
\hline Côté-Gravel et al. (84) & 2019 & Bovine mastitis isolates & Vaccine & S. aureus & Mice \\
\hline Marbach et al. (90) & 2019 & $\begin{array}{l}\text { Subclinical bovine mastitis } \\
\text { isolates, milk samples }\end{array}$ & $\begin{array}{l}\text { Interactions between host } \\
\text { and bacteria }\end{array}$ & S. aureus & Mice \\
\hline Wang et al. (72) & 2020 & Isolates (Purchased strains) & Antibacterial treatment & S. xylosus & Mice \\
\hline Prenafeta et al. (86) & 2010 & Ruminant mastitis isolates & Vaccine & S. aureus & Heifers, cows \\
\hline Savijoki et al. (91) & 2014 & Bovine mastitis isolates & Genomics and proteomics & S. epidermidis & Cows \\
\hline Seroussi et al. (92) & 2018 & Bovine mastitis isolates & Antibacterial treatment & E. coli, S. aureus & Cows \\
\hline Cucarella et al. (40) & 2004 & $\begin{array}{l}\text { Bovine subclinical mastitis } \\
\text { isolates }\end{array}$ & Molecular basis of biofilm & S. aureus & Sheep \\
\hline
\end{tabular}

described above very few in vivo investigations of mammary biofilm infections exist. Some studies have investigated the response of mammary cells to biofilm-producing strains of known mastitis-causing pathogens in vitro. The ability of $S$. aureus biofilm forming strains to adhere and invade the mammary cells is especially investigated. A study found that S. aureus biofilm showed lower invasion ability into mammary epithelial cells compared to planktonic $S$. aureus cultures and that the biofilm culture induced less cellular activation than the planktonic cultures. Both planktonic culture and S. aureus biofilm culture induced expression of interleukin 6 by mammary alveolar cells, which could be an anti-inflammatory response (94). This corresponds well to human research of biofilm infections and immune response, where biofilms do not trigger any specific immune responses (82) and downregulates specific virulence genes when the cell density is low to "fly under the radar" so the immune system does not detect the bacteria. Whenever the cell density is high enough, the bacteria can upregulate the virulence factors (95). However, other in vitro studies found no difference in the ability to invade host cells by non-biofilm producing mastitis strains compared to biofilm producing mastitis strains $(96,97)$. The role of the Bap protein expressed by $S$. aureus has been investigated in a lactating mouse model, where the surface protein Bap, involved in biofilm matrix, adhered to epithelial cells and bound to host receptor Gp96. The bacteria expressing the surface protein Bap did not invade the cells and had increased persistence in the mammary glands of the lactating mice, indicating that the protein promotes adhesion to the cells and limits invasion of the host cells (98).

The main question still not resolved is how the biofilms go undetected and survive the immune response (99) and more research is needed to answer that question both for mastitis and for all other biofilm infections. The current research is based on in vitro experiments and as discussed earlier in this review, more in vivo research is needed to fully understand the role of biofilm in mastitis.

\section{DISCUSSION}

The role of biofilm in the pathogenesis of bovine mastitis infection is still unclear. To the authors' best knowledge, only two papers investigate and detect the presence of biofilms inside udders from dairy cows with mastitis $(46,47)$. Plenty of in vitro studies investigate the biofilm forming abilities of mastitis pathogens isolated from milk samples. Similar to swabs and wound fluid samples, analyzing milk samples is a great, easy and quick way to investigate and culture the bacteria present in the samples and to determine, e.g., the genetic composition and antibiotic susceptibility. However, disadvantages are the risk of contamination from the environment and that it is only possible to detect bacteria present in or released into the milk, however bacteria embedded in the tissue, encapsulated bacteria, lowshedding bacteria, and potential biofilms might not be detectable in milk samples (100). Even if bacteria are isolated from milk samples and are able to form biofilm in vitro, this does not provide any information on the bacteria's phenotype in vivo in the infected udder. In vitro biofilms of $P$. aeruginosa have a markedly different genetic expression profile than in vivo biofilms during human infections (101). This is due to, e.g., the environment in the host tissue, interactions with the immune system, and antibiotic treatment that are impossible to fully mimic in vitro. Further, major physical differences exist between in vitro 
and in vivo biofilms; for example, in vitro biofilms normally form large mushroom-shaped structures, which are never observed in vivo, where the biofilms are markedly smaller in size (16).

Hence to find the actual role of biofilm in bovine mastitis, the approach needs to change from in vitro to in vivo investigations of biofilms in infected udders. When diagnosing biofilm infections in human medicine, the gold standard is to directly visualize the biofilms and concurrent immune response in the tissue. This can be done with, e.g., CLSM or scanning electron microscopy $(15,18,102)$. Sample collection for biofilm diagnosis naturally varies for different diseases/tissue, e.g., from cystic fibrosis patients, expectorated sputum samples, bronchoalveolar lavage, or biopsies from removed lung tissues during lung transplantation can be collected $(18,102)$, and from chronic wounds, biopsies or debrided tissue can be investigated (103). Especially in wound infections, the spatial distribution of different bacterial biofilms within the tissue can be observed using microscopic examination; this method has further found the pathogen $P$. aeruginosa to be underestimated when performing culture of standard wound swabs $(104,105)$. A good technique to detect bacterial biofilms in tissue is peptide nucleic acid fluorescence in situ hybridization (PNA-FISH), with probes that hybridize to bacterial ribosomal RNA, which can subsequently be detected using CLSM. This is a sensitive method that is well-established in the research of biofilm infections in humans $(102,104,106-108)$. This method would be applicable to udder tissue samples as well.

If biofilms are found present in mastitis udders, e.g., by use of the methods just described, the next question is whether the biofilms are part of the pathogenesis of bovine mastitis? Therefore, the immune response to the biofilms is also important to investigate. The cytological cure of mastitis is delayed compared to the bacteriological cure, meaning that when the infection appears cleared, the inflammation can continue in the udder (9). The cytological cure rate can be as low as around $20 \%$ and therefore it should be considered that chronic mastitis cases could be due to long-lasting inflammation, potentially driven by biofilms, after the apparent bacterial cure (9). The treatment of especially $S$. aureus mastitis cases is difficult, and therefore the connection between these cases and $S$. aureus biofilm presence and many virulence factors that are upregulated during mastitis infections should be further investigated $(10,11)$. We propose that udder cell and tissue models could potentially be applied to investigate how biofilms affect bovine udder tissue, however, studies of natural or experimentally induced mastitis will provide more information as a competent immune system would respond to the infection.

Collecting udder tissue biopsies from live dairy cows with mastitis for microscopy is difficult, if not impossible. However, biopsies can easily be obtained after euthanasia and by applying relevant staining and microscopy techniques, a more accurate view of biofilms' potential location and distribution as well as the related host immune response during mastitis can be revealed. Only a few papers provide information on biofilms' presence in udders from dairy cows with mastitis $(46,47)$ and more research is needed to elucidate biofilms' role in mastitis pathogenesis. Therefore, the collection of biopsies from euthanized animals might not have any direct clinical relevance, as the animals would be dead, but has important scientific relevance to better understand the disease and relate this to findings in milk samples. If biofilms play a role in bovine mastitis, diagnostic methods to detect biofilm in milk samples could be a possible way to easily diagnose the biofilms. However, for now, no such biofilm marker, specific biofilm product, or specific biofilm immune response have been identified that would be usable for quick and simple biofilm diagnostics neither in human or veterinary medicine. This is naturally the topic and aim of many human research groups' intense work, as biofilm infections play an important part of many human infections, and whenever found this would hopefully also be applicable to milk samples from bovine mastitis. By understanding the bacteria and biofilms including their interactions with the host immune system during mastitis infections, potentially new possible diagnostic methods could be developed as well as new optimized treatment options.

\section{CONCLUSIONS}

Bovine mastitis is one of the most important diseases in the dairy industry and a better understanding of the role of biofilm in the disease is of high importance to achieve more successful treatments. Chronic biofilm infections are recognized as serious and difficult-to-treat diseases in human medicine. The majority of the research on biofilm and bovine mastitis has so far focused on in vitro studies; however, to uncover the presence of biofilm in udders of dairy cows suffering from mastitis, direct methods need to be applied. Some of the methods used in the diagnosis and research of biofilms in human infections could be applied to the research of biofilm in bovine mastitis. There is a need for in vivo research where the location and distribution of biofilms are investigated directly in the udder of dairy cows with mastitis and where these findings are related to findings in milk samples. The continuous unsuccessful antibiotic treatment of potential biofilm mastitis infections can increase the risk of antibiotic resistance, which is one of the biggest threats to human and animal health. The role of biofilm infections in bovine mastitis therefore seems a key to unlock the required knowledge to develop new diagnostic methods and treat the persistent and chronic cases of bovine mastitis.

\section{METHODS}

This review has included studies that examine biofilm in relation to mastitis in dairy cows. We have included studies investigating biofilm abilities, molecular properties, treatment options, prevention and interactions of bovine mastitis related pathogens. Studies published since 2000 were included. Reviews and manuscripts in other languages than English have not been included in this review.

The literature search was carried out using the database Pubmed on October 1st 2020 with the search words "bovine mastitis + biofilm." Over 170 papers investigated the role of 
biofilm in bovine mastitis by in vitro methods and 16 papers used in vivo methods.

\section{AUTHOR CONTRIBUTIONS}

RP: original draft preparation, methodology, and writing. EJ: writing, editing, and supervision. VK, TB, KD-P, and RB: editing and supervision. All authors have read the manuscript and agreed to the published version.

\section{REFERENCES}

1. Viguier C, Arora S, Gilmartin N, Welbeck K, O'Kennedy R. Mastitis detection: current trends and future perspectives. Trends Biotechnol. (2009) 27:486-93. doi: 10.1016/j.tibtech.2009.05.004

2. Ruegg PL. A 100-year review: mastitis detection, management, and prevention. J Dairy Sci. (2017) 100:10381-97. doi: 10.3168/jds.2017-13023

3. Bradley A. Bovine mastitis: an evolving disease. Vet J. (2002) 164:116-28. doi: $10.1053 /$ tvjl.2002.0724

4. Adkins PRF, Middleton JR. Methods for diagnosing mastitis. Vet Clin North Am Food Anim Pract. (2018) 34:479-91. doi: 10.1016/j.cvfa.2018.07.003

5. Suojala L, Kaartinen L, Pyörälä S. Treatment for bovine Escherichia coli mastitis - an evidence-based approach. J Vet Pharmacol Ther. (2013) 36:52131. doi: 10.1111/jvp. 12057

6. Oliver SP, Almeida RA, Gillespie BE, Headrick SJ, Dowlen HH, Johnson DL, et al. Extended ceftiofur therapy for treatment of experimentally-induced Streptococcus uberis mastitis in lactating dairy cattle. J Dairy Sci. (2004) 87:3322-9. doi: 10.3168/jds.S0022-0302(04)73468-2

7. Wente N, Grieger AS, Klocke D, Paduch J-H, Zhang Y, Leimbach S, et al. Recurrent mastitis-persistent or new infections? Vet Microbiol. (2020) 244:108682. doi: 10.1016/j.vetmic.2020.108682

8. Lundberg Å, Nyman A-K, Aspán A, Börjesson S, Unnerstad HE, Waller KP. Udder infections with Staphylococcus aureus, Streptococcus dysgalactiae, and Streptococcus uberis at calving in dairy herds with suboptimal udder health. $J$ Dairy Sci. (2016) 99:2102-17. doi: 10.3168/jds.2015-9487

9. Schmenger A, Krömker V. Characterization, cure rates and associated risks of clinical mastitis in Northern Germany. Vet Sci. (2020) 7:170. doi: $10.3390 /$ vetsci7040170

10. Zecconi A, Cesaris L, Liandris E, Daprà V, Piccinini R. Role of several Staphylococcus aureus virulence factors on the inflammatory response in bovine mammary gland. Microb Pathog. (2006) 40:177-83. doi: 10.1016/j.micpath.2006.01.001

11. Oogai Y, Matsuo M, Hashimoto M, Kato F, Sugai M, Komatsuzawa H. Expression of virulence factors by Staphylococcus aureus grown in serum. Appl Environ Microbiol. (2011) 77:8097-105. doi: 10.1128/AEM.05316-11

12. Pérez VKC, Custódio DAC, Silva EMM, de Oliveira J, Guimarães AS, Brito MAVP, et al. Virulence factors and antimicrobial resistance in Staphylococcus aureus isolated from bovine mastitis in Brazil. Braz J Microbiol. (2020) 51:2111-22. doi: 10.1007/s42770-020-00363-5

13. Hamel J, Zhang Y, Wente N, Krömker V. Non-S. aureus staphylococci (NAS) in milk samples: Infection or contamination? Vet Microbiol. (2020) 242:108594. doi: 10.1016/j.vetmic.2020.108594

14. Dhingra S, Rahman NAA, Peile E, Rahman M, Sartelli M, Hassali MA, et al. Microbial resistance movements: an overview of global public health threats posed by antimicrobial resistance, and how best to counter. Front Public Health. (2020) 8:535668. doi: 10.3389/fpubh.2020.535668

15. Burmølle M, Thomsen TR, Fazli M, Dige I, Christensen L, Homøe P, et al. Biofilms in chronic infections - A matter of opportunity - Monospecies biofilms in multispecies infections. FEMS Immunol Med Microbiol. (2010) 59:324-36. doi: 10.1111/j.1574-695X.2010.00714.x

16. Bjarnsholt T, Alhede M, Alhede M, Eickhardt-Sørensen SR, Moser C, Kühl M, et al. The in vivo biofilm. Trends Microbiol. (2013) 21:466-74. doi: 10.1016/j.tim.2013.06.002

\section{FUNDING}

This research was funded by the Danish Veterinary and Food Administration.

\section{ACKNOWLEDGMENTS}

The authors would like to thank Ida Thaarup for ideas and comments to the manuscript.

17. Flemming HC, Wingender J, Szewzyk U, Steinberg P, Rice SA, Kjelleberg S. Biofilms: an emergent form of bacterial life. Nat Rev Microbiol. (2016) 14:563-75. doi: 10.1038/nrmicro.2016.94

18. Høiby N, Bjarnsholt T, Moser C, Bassi GL, Coenye T, Donelli G, et al. ESCMID guideline for the diagnosis and treatment of biofilm infections 2014. Clin Microbiol Infect. (2015) 21:S1-S25. doi: 10.1016/j.cmi.2014.10.024

19. Høiby N, Ciofu O, Johansen HK, Song ZJ, Moser C, Jensen PØ, et al. The clinical impact of bacterial biofilms. Int J Oral Sci. (2011) 3:55-65. doi: $10.4248 /$ IJOS 11026

20. Hall-Stoodley L, Costerton JW, Stoodley P. Bacterial biofilms: from the natural environment to infectious diseases. Nat Rev Microbiol. (2004) 2:95108. doi: $10.1038 /$ nrmicro821

21. Hoiby N. Pseudomonas aeruginosa infection in cystic fibrosis. Diagnostic and prognostic significance of Pseudomonas aeruginosa precipitins determined by means of crossed immunoelectrophoresis. A survey. Acta Pathol Microbiol Scand Suppl. (1977) 58:1-96.

22. Marrie TJ, Nelligan J, Costerton JW. A scanning and transmission electron microscopic study of an infected endocardial pacemaker lead. Circulation. (1982) 66:1339-41. doi: 10.1161/01.CIR.66.6.1339

23. Lebeaux D, Ghigo J-M. Management of biofilm-associated infections: what can we expect from recent research on biofilm lifestyles? Med Sci (Paris). (2012) 28:727-39. doi: 10.1051/medsci/2012288015

24. Bhagirath AY, Li Y, Somayajula D, Dadashi M, Badr S, Duan K. Cystic fibrosis lung environment and Pseudomonas aeruginosa infection. BMC Pulm Med. (2016) 16:174. doi: 10.1186/s12890-016-0339-5

25. Bjarnsholt T. The role of bacterial biofilms in chronic infections. APMIS Suppl. (2013) 136:1-51. doi: 10.1111/apm.12099

26. Stephenson AL, Tom M, Berthiaume Y, Singer LG, Aaron SD, Whitmore GA, et al. A contemporary survival analysis of individuals with cystic fibrosis: a cohort study. Eur Respir J. (2015) 45:670-9. doi: 10.1183/09031936.00119714

27. Bjarnsholt T, Kirketerp-Møller K, Jensen PØ, Madsen KG, Phipps R, Krogfelt $\mathrm{K}$, et al. Why chronic wounds will not heal: a novel hypothesis. Wound repair. (2008) 16:2-10. doi: 10.1111/j.1524-475X.2007.00283.x

28. Malone M, Bjarnsholt T, McBain AJ, James GA, Stoodley P, Leaper D, et al. The prevalence of biofilms in chronic wounds: a systematic review and meta-analysis of published data. J Wound Care. (2017) 26:20-5. doi: 10.12968/jowc.2017.26.1.20

29. James GA, Swogger E, Wolcott R, Pulcini E deLancey, Secor P, Sestrich $\mathrm{J}$, et al. Biofilms in chronic wounds. Wound repair. (2008) 16:37-44. doi: 10.1111/j.1524-475X.2007.00321.x

30. Gjødsbøl K, Christensen JJ, Karlsmark T, Jørgensen B, Klein BM, Krogfelt KA. Multiple bacterial species reside in chronic wounds: a longitudinal study. Int Wound J. (2006) 3:225-31. doi: 10.1111/j.1742-481X.2006.00159.x

31. Wolcott RD, Hanson JD, Rees EJ, Koenig LD, Phillips CD, Wolcott RA, et al. Analysis of the chronic wound microbiota of 2,963 patients by $16 \mathrm{~S}$ rDNA pyrosequencing. Wound Repair. (2016) 24:163-74. doi: 10.1111/wrr. 12370

32. Trampuz A, Zimmerli W. Diagnosis and treatment of implant-associated septic arthritis and osteomyelitis. Curr Infect Dis Rep. (2008) 10:394-403. doi: 10.1007/s11908-008-0064-1

33. Jakobsen TH, Eickhardt SR, Gheorghe AG, Stenqvist C, Sønderholm M, Stavnsberg C, et al. Implants induce a new niche for microbiomes. APMIS. (2018) 126:685-92. doi: 10.1111/apm.12862 
34. Wolcott RD, Rhoads DD, Bennett ME, Wolcott BM, Gogokhia L, Costerton JW, et al. Chronic wounds and the medical biofilm paradigm. J Wound Care. (2010) 19:45-6, 48-50, 52-53. doi: 10.12968/jowc.2010.19.2.46966

35. Baselga R, Albizu I, De La Cruz M, Del Cacho E, Barberan M, Amorena B. Phase variation of slime production in Staphylococcus aureus: implications in colonization and virulence. Infect Immun. (1993) 61:485762. doi: 10.1128/IAI.61.11.4857-4862.1993

36. Ali-Vehmas T, Westphalen P, Myllys V, Sandholm M. Binding of Staphylococcus aureus to milk fat globules increases resistance to penicillinG. J Dairy Res. (1997) 64:253-60. doi: 10.1017/S0022029996002026

37. Fox LK, Zadoks RN, Gaskins CT. Biofilm production by Staphylococcus aureus associated with intramammary infection. Vet Microbiol. (2005) 107:295-9. doi: 10.1016/j.vetmic.2005.02.005

38. Oliveira M, Nunes SF, Carneiro C, Bexiga R, Bernardo F, Vilela CL. Time course of biofilm formation by Staphylococcus aureus and Staphylococcus epidermidis mastitis isolates. Vet Microbiol. (2007) 124:18791. doi: 10.1016/j.vetmic.2007.04.016

39. Melchior MB, van Osch MHJ, Graat RM, van Duijkeren E, Mevius DJ, Nielen $\mathrm{M}$, et al. Biofilm formation and genotyping of Staphylococcus aureus bovine mastitis isolates: evidence for lack of penicillin-resistance in Agr-type II strains. Vet Microbiol. (2009) 137:83-9. doi: 10.1016/j.vetmic.2008.12.004

40. Cucarella C, Tormo MA, Ubeda C, Trotonda MP, Monzón M, Peris $\mathrm{C}$, et al. Role of biofilm-associated protein bap in the pathogenesis of bovine Staphylococcus aureus. Infect Immun. (2004) 72:2177-85. doi: 10.1128/IAI.72.4.2177-2185.2004

41. Vasudevan P, Nair MKM, Annamalai T, Venkitanarayanan KS. Phenotypic and genotypic characterization of bovine mastitis isolates of Staphylococcus aureus for biofilm formation. Vet Microbiol. (2003) 92:179-85. doi: 10.1016/S0378-1135(02)00360-7

42. Melchior MB, Vaarkamp H, Fink-Gremmels J. Biofilms: a role in recurrent mastitis infections? Vet J. (2006) 171:398-407. doi: 10.1016/j.tvjl.2005.01.006

43. Arrizubieta MJ, Toledo-Arana A, Amorena B, Penadés JR, Lasa I. Calcium inhibits bap-dependent multicellular behavior in Staphylococcus aureus. J Bacteriol. (2004) 186:7490-8. doi: 10.1128/JB.186.22.7490-7498.2004

44. Brouillette E, Hyodo M, Hayakawa Y, Karaolis DKR, Malouin F. 3',5'-cyclic diguanylic acid reduces the virulence of biofilm-forming Staphylococcus aureus strains in a mouse model of mastitis infection. Antimicrob Agents Chemother. (2005) 49:3109-13. doi: 10.1128/AAC.49.8.3109-3113.2005

45. Karaolis DKR, Rashid MH, Chythanya R, Luo W, Hyodo M, Hayakawa Y. cdi-GMP (3'-5'-cyclic diguanylic acid) inhibits Staphylococcus aureus cell-cell interactions and biofilm formation. Antimicrob Agents Chemother. (2005) 49:1029-38. doi: 10.1128/AAC.49.3.1029-1038.2005

46. Schönborn S, Krömker V. Detection of the biofilm component polysaccharide intercellular adhesin in Staphylococcus aureus infected cow udders. Vet Microbiol. (2016) 196:126-8. doi: 10.1016/j.vetmic.2016.10.023

47. Hensen SM, Pavičić MJAMP, Lohuis JACM, De Hoog JAM, Poutrel B. Location of Staphylococcus aureus within the experimentally infected Bovine Udder and the expression of capsular polysaccharide type 5 in situ. J Dairy Sci. (2000) 83:1966-75. doi: 10.3168/jds.S0022-0302(00)75073-9

48. Moormeier DE, Bayles KW. Staphylococcus aureus biofilm: a complex developmental organism. Mol Microbiol. (2017) 104:365-76. doi: $10.1111 / \mathrm{mmi} .13634$

49. Rossi BF, Bonsaglia ECR, Castilho IG, Dantas STA, Salina A, Langoni $\mathrm{H}$, et al. Genotyping of long term persistent Staphylococcus aureus in bovine subclinical mastitis. Microb Pathog. (2019) 132:45-50. doi: 10.1016/j.micpath.2019.04.031

50. Stiefel P, Rosenberg U, Schneider J, Mauerhofer S, Maniura-Weber K, Ren Q. Is biofilm removal properly assessed? Comparison of different quantification methods in a 96-well plate system. Appl Microbiol Biotechnol. (2016) 100:4135-45. doi: 10.1007/s00253-016-7396-9

51. Azeredo J, Azevedo NF, Briandet R, Cerca N, Coenye T, Costa AR, et al. Critical review on biofilm methods. Crit Rev Microbiol. (2017) 43:313-51. doi: 10.1080/1040841X.2016.1208146

52. Darwish SF, Asfour HAE. Investigation of biofilm forming ability in Staphylococci causing bovine mastitis using phenotypic and genotypic assays. Sci World J. (2013) 2013:378492. doi: 10.1155/2013/378492

53. Notcovich S, DeNicolo G, Flint SH, Williamson NB, Gedye K, Grinberg A, et al. Biofilm-forming potential of Staphylococcus aureus isolated from clinical mastitis cases in New Zealand. Vet Sci. (2018) 5:8. doi: 10.3390/vetsci5010008

54. Salimena APS, Lange CC, Camussone C, Signorini M, Calvinho LF, Brito MAVP, et al. Genotypic and phenotypic detection of capsular polysaccharide and biofilm formation in Staphylococcus aureus isolated from bovine milk collected from Brazilian dairy farms. Vet Res Commun. (2016) 40:97-106. doi: 10.1007/s11259-016-9658-5

55. Bonsaglia ECR, Latosinski GS, Rossi RS, Rossi BF, Possebon FS, Pantoja JCF, et al. Biofilm production under different atmospheres and growth media by Streptococcus agalactiae isolated from milk of cows with subclinical mastitis. Arch Microbiol. (2020) 202:209-12. doi: 10.1007/s00203-019-01727-8

56. Pang M, Sun L, He T, Bao H, Zhang L, Zhou Y, et al. Molecular and virulence characterization of highly prevalent Streptococcus agalactiae circulated in bovine dairy herds. Vet Res. (2017) 48:65. doi: 10.1186/s13567-017-0461-2

57. Varhimo E, Varmanen P, Fallarero A, Skogman M, Pyörälä S, Iivanainen A, et al. Alpha- and $\beta$-casein components of host milk induce biofilm formation in the mastitis bacterium Streptococcus uberis. Vet Microbiol. (2011) 149:381-9. doi: 10.1016/j.vetmic.2010.11.010

58. Sela S, Hammer-Muntz O, Krifucks O, Pinto R, Weisblit L, Leitner G. Phenotypic and genotypic characterization of Pseudomonas aeruginosa strains isolated from mastitis outbreaks in dairy herds. J Dairy Res. (2007) 74:425-9. doi: 10.1017/S0022029907002610

59. Massé J, Dufour S, Archambault M. Characterization of Klebsiella isolates obtained from clinical mastitis cases in dairy cattle. J Dairy Sci. (2020) 103:3392-400. doi: 10.3168/jds.2019-17324

60. Freeman DJ, Falkiner FR, Keane CT. New method for detecting slime production by coagulase negative staphylococci. J Clin Pathol. (1989) 42:8724. doi: $10.1136 /$ jcp.42.8.872

61. Dhanawade NB, Kalorey DR, Srinivasan R, Barbuddhe SB, Kurkure N V. Detection of intercellular adhesion genes and biofilm production in Staphylococcus aureus isolated from bovine subclinical mastitis. Vet Res Commun. (2010) 34:81-9. doi: 10.1007/s11259-009-9326-0

62. Castelani L, Pilon LE, Martins T, Pozzi CR, Arcaro JRP. Investigation of biofilm production and icaA and icaD genes in Staphylococcus aureus isolated from heifers and cows with mastitis. Anim Sci J. (2015) 86:340-4. doi: 10.1111 /asj.12284

63. Christensen GD, Simpson WA, Bisno AL, Beachey EH. Adherence of slimeproducing strains of Staphylococcus epidermidis to smooth surfaces. Infect Immun. (1982) 37:318-26. doi: 10.1128/IAI.37.1.318-326.1982

64. Aslantaş Ö, Demir C. Investigation of the antibiotic resistance and biofilmforming ability of Staphylococcus aureus from subclinical bovine mastitis cases. J Dairy Sci. (2016) 99:8607-13. doi: 10.3168/jds.2016-11310

65. Shah MS, Qureshi S, Kashoo Z, Farooq S, Wani SA, Hussain MI, et al. Methicillin resistance genes and in vitro biofilm formation among Staphylococcus aureus isolates from bovine mastitis in India. Comp Immunol Microbiol Infect Dis. (2019) 64:117-24. doi: 10.1016/j.cimid.2019.02.009

66. Tremblay YDN, Lamarche D, Chever P, Haine D, Messier S, Jacques M. Characterization of the ability of coagulase-negative staphylococci isolated from the milk of Canadian farms to form biofilms. J Dairy Sci. (2013) 96:234-46. doi: 10.3168/jds.2012-5795

67. Silva VO, Soares LO, Silva Júnior A, Mantovani HC, Chang Y-F, Moreira MAS. Biofilm formation on biotic and abiotic surfaces in the presence of antimicrobials by Escherichia coli Isolates from cases of bovine mastitis. Appl Environ Microbiol. (2014) 80:6136-45. doi: 10.1128/AEM. 01953-14

68. Costa M, Freitas I De. Increased production of biofilms by Escherichia coli in the presence of enrofloxacin. Vet Microbiol. (2012) 160:488-90. doi: 10.1016/j.vetmic.2012.05.036

69. Nascimento FR, Albuquerque KRS, Oliveira MR, Pizziolo VR, Brasileiro BG, Diaz G, et al. Antibiotic activity of Plectranthus ornatus Codd., a Traditional Medicinal Plant. An Acad Bras Cienc. (2017) 89:2461-9. doi: 10.1590/0001-3765201720170068

70. Mordmuang A, Brouillette E, Voravuthikunchai SP, Malouin F. Evaluation of a Rhodomyrtus tomentosa ethanolic extract for its therapeutic potential on Staphylococcus aureus infections using in vitro and in vivo models of mastitis. Vet Res. (2019) 50:49. doi: 10.1186/s13567-019-0664-9

71. Cerioli MF, Moliva MV, Cariddi LN, Reinoso EB. Effect of the essential oil of Minthostachys verticillata (Griseb.) epling and limonene on biofilm 
production in pathogens causing bovine mastitis. Front Vet Sci. (2018) 5:146. doi: 10.3389/fvets.2018.00146

72. Wang J, Qu Q, Liu X, Cui W, Yu F, Chen X, Xing X, Zhou Y, Yang Y, Bello-Onaghise G, et al. 1-Hydroxyanthraquinone exhibited antibacterial activity by regulating glutamine synthetase of Staphylococcus xylosus as a virulence factor. Biomed Pharmacother. (2020) 123:109779. doi: 10.1016/j.biopha.2019.109779

73. Rumi MV, Huguet MJ, Bentancor AB, Gentilini ER. The icaA gene in staphylococci from bovine mastitis. J Infect Dev Ctries. (2013) 7:556-560. doi: $10.3855 /$ jidc. 2670

74. Szweda P, Schielmann M, Milewski S, Frankowska A, Jakubczak A. Biofilm production and presence of ica and bap genes in Staphylococcus aureus strains isolated from cows with mastitis in the eastern Poland. Polish J Microbiol. (2012) 61:65-9. doi: 10.33073/pjm-2012-009

75. Tan CH, Lee KWK, Burmølle M, Kjelleberg S, Rice SA. All together now: experimental multispecies biofilm model systems. Environ Microbiol. (2017) 19:42-53. doi: 10.1111/1462-2920.13594

76. Burmølle M, Ren D, Bjarnsholt T, Sørensen SJ. Interactions in multispecies biofilms: do they actually matter? Trends Microbiol. (2014) 22:84-91. doi: 10.1016/j.tim.2013.12.004

77. Frola ID, Pellegrino MS, Espeche MC, Giraudo JA, Nader-Macias ME, Bogni CI. Effects of intramammary inoculation of Lactobacillus perolens CRL1724 in lactating cows' udders. J Dairy Res. (2012) 79:84-92. doi: 10.1017/S0022029911000835

78. Wallis JK, Krömker V, Paduch J-H. Biofilm challenge: lactic acid bacteria isolated from bovine udders versus staphylococci. Foods. (2019) 8:79 doi: 10.3390/foods8020079

79. Ren X, Wang L, Chen W. Oxytropis glabra DC. Inhibits Biofilm Formation of Staphylococcus epidermidis by Down-regulating ica operon expression. Curr Microbiol. (2020) 77:1167-73. doi: 10.1007/s00284-019-01847-w

80. Wolcott R, Costerton JW, Raoult D, Cutler SJ. The polymicrobial nature of biofilm infection. Clin Microbiol Infect. (2013) 19:107-12. doi: 10.1111/j.1469-0691.2012.04001.x

81. Brown SP, Fredrik Inglis R, Taddei F. Evolutionary ecology of microbial wars: within-host competition and (incidental) virulence. Evol Appl. (2009) 2:32-9. doi: 10.1111/j.1752-4571.2008.00059.x

82. Jensen PØ, Givskov M, Bjarnsholt T, Moser C. The immune system vs. Pseudomonas aeruginosa biofilms. FEMS Immunol Med Microbiol. (2010) 59:292-305. doi: 10.1111/j.1574-695X.2010.00706.x

83. Collado R, Prenafeta A, González-González L, Pérez-Pons JA, Sitjà M. Probing vaccine antigens against bovine mastitis caused by Streptococcus uberis. Vaccine. (2016) 34:3848-54. doi: 10.1016/j.vaccine.2016. 05.044

84. Côté-Gravel J, Brouillette E, Malouin F. Vaccination with a liveattenuated small-colony variant improves the humoral and cell-mediated responses against Staphylococcus aureus. PLoS One. (2019) 14:e0227109. doi: 10.1371/journal.pone.0227109

85. Gogoi-Tiwari J, Williams V, Waryah CB, Eto KY, Tau M, Costantino P, et al. Comparative studies of the immunogenicity and protective potential of biofilm vs planktonic Staphylococcus aureus vaccine against bovine mastitis using non-invasive mouse mastitis as a model system. Biofouling. (2015) 31:543-54. doi: 10.1080/08927014.2015.1074681

86. Prenafeta A, March R, Foix A, Casals I, Costa L. Study of the humoral immunological response after vaccination with a Staphylococcus aureus biofilm-embedded bacterin in dairy cows: possible role of the exopolysaccharide specific antibody production in the protection from Staphylococcus aureus induced mastitis. Vet Immunol Immunopathol. (2010) 134:208-17. doi: 10.1016/j.vetimm.2009.09.020

87. Gogoi-Tiwari J, Williams V, Waryah CB, Mathavan S, Tiwari HK, Costantino $\mathrm{P}$, et al. Intramammary immunization of pregnant mice with staphylococcal protein a reduces the post-challenge mammary gland bacterial load but not pathology. PLoS One. (2016) 11:e0148383. doi: 10.1371/journal.pone.0148383

88. Cucarella C, Solano C, Valle J, Amorena B, Lasa I, Penadés JR. Bap, a Staphylococcus aureus surface protein involved in biofilm formation. J Bacteriol. (2001) 183:2888-96. doi: 10.1128/JB.183.9.28882896.2001
89. Montironi ID, Moliva M V, Campra NA, Raviolo JM, Bagnis G, Cariddi LN. Characterization of an Enterococcus faecium strain in a murine mastitis model. J Appl Microbiol. (2019) 128:1289-300. doi: 10.1111/jam. 14554

90. Marbach H, Mayer K, Vogl C, Lee JYH, Monk IR, Sordelli DO, et al. Within-host evolution of bovine Staphylococcus aureus selects for a SigB-deficient pathotype characterized by reduced virulence but enhanced proteolytic activity and biofilm formation. Sci Rep. (2019) 9:13479. doi: 10.1038/s41598-019-49981-6

91. Savijoki K, Iivanainen A, Siljamäki P, Laine PK, Paulin L, Karonen $\mathrm{T}$, et al. Genomics and proteomics provide new insight into the commensal and pathogenic lifestyles of bovine- and human-associated Staphylococcus epidermidis strains. J Proteome Res. (2014) 13:3748-62. doi: $10.1021 /$ pr500322d

92. Seroussi E, Blum SE, Krifucks O, Lavon Y, Leitner G. Application of pancreatic phospholipase A2 for treatment of bovine mastitis. PLoS One. (2018) 13:e0203132. doi: 10.1371/journal.pone.0203132

93. Sordillo LM. Mammary gland immunobiology and resistance to mastitis. Vet Clin North Am Food Anim Pract. (2018) 34:507-23. doi: 10.1016/j.cvfa.2018.07.005

94. Bohl LP, Isaac P, Breser ML, Orellano MS, Correa SG, Tolosa de Talamoni $\mathrm{NG}$, et al. Interaction between bovine mammary epithelial cells and planktonic or biofilm Staphylococcus aureus: the bacterial lifestyle determines its internalization ability and the pathogen recognition. Microb Pathog. (2021) 152:104604. doi: 10.1016/j.micpath.2020. 104604

95. Bjarnsholt T, Givskov M. The role of quorum sensing in the pathogenicity of the cunning aggressor Pseudomonas aeruginosa. Anal Bioanal Chem. (2007) 387:409-14. doi: 10.1007/s00216-006-0774-x

96. Zaatout N, Ayachi A, Kecha M. Interaction of primary mammary bovine epithelial cells with biofilm-forming staphylococci associated with subclinical bovine mastitis. Iran J Vet Res. (2019) 20:27-32.

97. Oliveira M, Bexiga R, Nunes SF, Vilela CL. Invasive potential of biofilmforming Staphylococci bovine subclinical mastitis isolates. J Vet Sci. (2011) 12:95-7. doi: 10.4142/jvs.2011.12.1.95

98. Valle J, Latasa C, Gil C, Toledo-Arana A, Solano C, Penadés JR, et al. Bap, a biofilm matrix protein of Staphylococcus aureus prevents cellular internalization through binding to GP96 host receptor. PLoS Pathog. (2012) 8:e1002843. doi: 10.1371/journal.ppat.1002843

99. Mulcahy LR, Isabella VM, Lewis K. Pseudomonas aeruginosa biofilms in disease. Microb Ecol. (2014) 68:1-12. doi: 10.1007/s00248-0130297-x

100. Krömker V, Friedrich J, Klocke C. Ausscheidung und Nachweis von Staphylococcus aureus über Milch aus infizierten Milchdrüsenvierteln. [Excretion and detection of Staphylococcus aureus via milk from infected mammary gland quarters]. Tierärztl Prax. (2008) 389-392. doi: 10.1055/s-0038-1623865

101. Cornforth DM, Dees JL, Ibberson CB, Huse HK, Mathiesen IH, Kirketerp-Møller K, et al. Pseudomonas aeruginosa transcriptome during human infection. Proc Natl Acad Sci U S A. (2018) 115:E5125-E34. doi: $10.1073 /$ pnas. 1717525115

102. Høiby N, Bjarnsholt T, Moser C, Jensen PØ, Kolpen M, Qvist T, et al. Diagnosis of biofilm infections in cystic fibrosis patients. APMIS. (2017) 125:339-43. doi: 10.1111/apm.12689

103. Thomsen TR, Aasholm MS, Rudkjøbing VB, Saunders AM, Bjarnsholt T, Givskov M, et al. The bacteriology of chronic venous leg ulcer examined by culture-independent molecular methods. Wound repair. (2010) 18:38-49. doi: 10.1111/j.1524-475X.2009.00561.x

104. Kirketerp-Møller K, Jensen PØ, Fazli M, Madsen KG, Pedersen J, Moser C, et al. Distribution, organization, and ecology of bacteria in chronic wounds. J Clin Microbiol. (2008) 46:2717-22. doi: 10.1128/JCM.00501-08

105. Fazli M, Bjarnsholt T, Kirketerp-Møller K, Jørgensen B, Andersen AS, Krogfelt KA, et al. Nonrandom distribution of Pseudomonas aeruginosa and Staphylococcus aureus in chronic wounds. J Clin Microbiol. (2009) 47:4084-9. doi: 10.1128/JCM.01395-09

106. Fazli M, Bjarnsholt T, Høiby N, Givskov M, Tolker-Nielsen T. PNA-based fluorescence in situ hybridization for identification of 
bacteria in clinical samples. Methods Mol Biol. (2014) 1211:261-71. doi: 10.1007/978-1-4939-1459-3_21

107. Rudkjøbing VB, Thomsen TR, Xu Y, Melton-Kreft R, Ahmed A, Eickhardt $S$, et al. Comparing culture and molecular methods for the identification of microorganisms involved in necrotizing soft tissue infections. BMC Infect Dis. (2016) 16:652. doi: 10.1186/s12879-016-1976-2

108. Malic S, Hill KE, Hayes A, Percival SL, Thomas DW, Williams DW. Detection and identification of specific bacteria in wound biofilms using peptide nucleic acid fluorescent in situ hybridization (PNA FISH). Microbiology. (2009) 155:2603-11. doi: 10.1099/mic.0. 028712-0
Conflict of Interest: The authors declare that the research was conducted in the absence of any commercial or financial relationships that could be construed as a potential conflict of interest.

Copyright () 2021 Pedersen, Krömker, Bjarnsholt, Dahl-Pedersen, Buhl and Jørgensen. This is an open-access article distributed under the terms of the Creative Commons Attribution License (CC BY). The use, distribution or reproduction in other forums is permitted, provided the original author(s) and the copyright owner(s) are credited and that the original publication in this journal is cited, in accordance with accepted academic practice. No use, distribution or reproduction is permitted which does not comply with these terms. 


\section{NOMENCLATURE}

CNS, Coagulase-negative staphylococci

CRA, Congo Red Agar

CLSM, confocal laser scanning microscopy

LAB, lactic acid bacteria

PIA, polysaccharide interstellar adhesions

PNA-FISH, peptide nucleic acid fluorescence in situ

hybridization. 